\title{
Morphological Study of the Teeth of Ambystoma maculatum, Salamandra salamandra and Aneides lugubris: Fine Structure and Chemistry of Enamel
}

\author{
By \\ Iwao SATO*1, Kazuyuki SHIMADA*2, Tooru SATO*1 and Richard ETHERIGE*3 \\ 'Department of Anatomy, Nippon Dental University, School of Dentistry at Tokyo, Tokyo 102, Japan. ${ }^{2}$ Department of \\ Anatomy, Showa University, School of Medicine, Tokyo 143, Japan. ${ }^{3}$ Department of Biology, College of Sciences. San \\ Diego State University, San Diego, California, 92182-0057, U.S.A.
}

- Received for Publication, April 19, $1993-$

Key Words: Amphibians, Teeth, Enamel, Elemental analysis

\begin{abstract}
Summary: The functional teeth of adult salamander (Caudata): Ambystoma maculatum, Salamandra salamandra and Aneides lugubris were prepared for transmission electron microscopy and electron microprobe analysis of the elements and trace elements of the enamel layer. The arrangement of enamel crystals in these species is variable. The outer part of the enamel layer in which hydroxyapatite elements $(\mathrm{Ca}, \mathrm{P})$ and trace elements $(\mathrm{e} . \mathrm{g} ., \mathrm{F}, \mathrm{Fe}, \mathrm{Mg})$ are concentrated, is most mineralized. The concentration of trace elements are arrangement of crystals in the enamel layer differed in these species, may be related to the pattern of mineralization of enamel.
\end{abstract}

The teeth of most modern living amphibians are composed of a distal crown and a basal pedicel. The crown is composed of highly mineralized with thin enamel and dentin layers (Schmidt, 1971; Zaki and Weber, 1979). The outer enamel layer of the teeth of Andrias davidianus and Onychodactylus japonicus is mainly composed of hydroxyapatite, but there are concentrations of trace elements, iron and fluorine (Sato et al., 1991). In general, matrices of crystals contain trace elements but their distribution and level differ in Caudata and Apoda (Sato et al., 1992) from rats (Halse, 1972; Halse and Selvig, 1974; Weatherell et al., 1975; Heap et al., 1983; Nelson et al., 1989) and alligator (Sato et al., 1990). The difference in concentration of elements and trace elements in the tooth distinguishes the enamel layer from the other layers, for example, the inner part of enamel layer, enameloid, and the dentin layer (Sato et al., 1992). The content level of elements in the enamel layer is presumably related to the variable structure and mineralization in the salamander tooth.

This study describes differences among some species of terrestial biosphere salamander examined, in the fine structure and distribution of elements and trace elements in the enamel layer, using transmission electron microscopy and electron micro- probe analysis.

\section{Materials and Methods}

In order to analyze the content and distribution of calcium, phosphorus, magnesium, iron, zinc, aluminum, chromium, molybdenum, lead, manganese, copper, tin and fluorine on the surface layer of enamel and dentin, a total ten teeth of each species were examined (Table 1). All skeletons that pro-

Table 1. Tabulation of the caudata and specimens cxamined during this study.

\begin{tabular}{lccc}
\hline $\begin{array}{l}\text { Supraspecific } \\
\text { classification }\end{array}$ & $\begin{array}{c}\text { Species } \\
\text { cxamined }\end{array}$ & $\begin{array}{c}\text { Specimens } \\
\text { examined }\end{array}$ & Aged \\
\hline $\begin{array}{l}\text { Order Caudata } \\
\text { Family Ambystomatidae } \\
\text { Ambystoma }\end{array}$ & A. maculatum & *SDSU 32 & Adult \\
$\begin{array}{c}\text { Family Salamandridae } \\
\text { Salamandra }\end{array}$ & S. salamandra & SDSU 2199 & Adult \\
$\begin{array}{c}\text { Family Plethodontidae } \\
\text { Aneides }\end{array}$ & A. lugubris & SDSU 0.52 & Adult \\
\hline
\end{tabular}

* SDSU, San Dicgo State Universit 
vided teeth for this study were prepared from dried carcasses by dermestid beetles, and cleaned with a brief exposure to commercial group laundry bleach, followed by $10 \mathrm{~min}$. soak in $95 \%$ ethanol. These materials were fixed for $30 \mathrm{~min}$., in $10 \%$ paraformalin solution, then dehydrated in acetone, finally embedded in epoxy resin (Epon-812). Silver-gray longitudinal planoparallel sections cut with an ultramicrotome (ULTRACUT, Reichert-Jung) were observed under a Hitachi $\mathrm{H}-700$ transmission electron microscope (TEM). A $3 \mathrm{~nm}$ thick layer of carbon was vacuum-evaporated on the surface of other sections, observed under a Shimazu EMX-SM electron microprobe analyzer (EMPA), with an accelerating voltage of $20 \mathrm{kV}$ (current, $70 \mathrm{nA}$ ) and $15 \mathrm{kV}$ (current, $80 \mathrm{nA}$ ) (Fig. 1). Enamel and underlying dentin were systematically investigated by electron microprobe analysis to determine concentrations of $\mathrm{Ca}, \mathrm{P}$, and trace elements at successive apico-basal level (Fig. 1a) at two different depth from the surface into inferior of the tonth (Fig. 1b). Line scan and points analysis of characteristic X-rays $(\mathrm{CaK} \alpha$, $\mathrm{PK} \alpha, \operatorname{MgK} \alpha, \operatorname{FeK} \alpha, \operatorname{AlK} \alpha, \operatorname{CrK} \alpha, \operatorname{Mok} \alpha, \operatorname{PdK} \alpha$, $\operatorname{MnK} \alpha, \operatorname{CuK} \alpha, \operatorname{SnK} \alpha, \mathrm{FK} \alpha$ ) detected only $\mathrm{Ca}, \mathrm{P}$, $\mathrm{Mg}, \mathrm{Fe}$, and $\mathrm{F}$ contents in the enamel of their teeth.

\section{Results}

\section{TEM observations}

The high density enamel layer in the teeth varied in thickness, about $10-28 \mu \mathrm{m}$ width at bicusp, and reducing in thickness near the pedicel (Table 2) (Fig. 1). The tooth of Ambystoma maculatum had the thickest enamel layer, about $28 \mu \mathrm{m}$ width at the elongated cusp. The arrangement of crystals in the enamel layer varied among the species (Table 2) (Figs. 2-4). Very small crystals of the enamel layer are packed, where they formed a high density area, regularly arranged to the tooth surface in contrast to dentin layer in Salamandra salamandra (Fig. 3). In the outer part of the enamel layer of Aneides lugubris and Ambystoma maculatum, though the crystals orientated irregularly to the long axis of the tooth, their arrangement in the rest of the enamel is in prism-like blocks oriented irregularly in relation to the tooth surface (Figs. 2, 4). At the dentino-enamel junction (DEJ), very small crystals were arranged irregularly, where they formed numerous small blocks, and masses in the tooth of Ambystoma and Aneides (Figs. 2, 4). Many minute crystals occurred between numerous collagen fibers in the dentin layer beneath the DEJ, where they distinguished as a high density area in contrast to other dentin layers

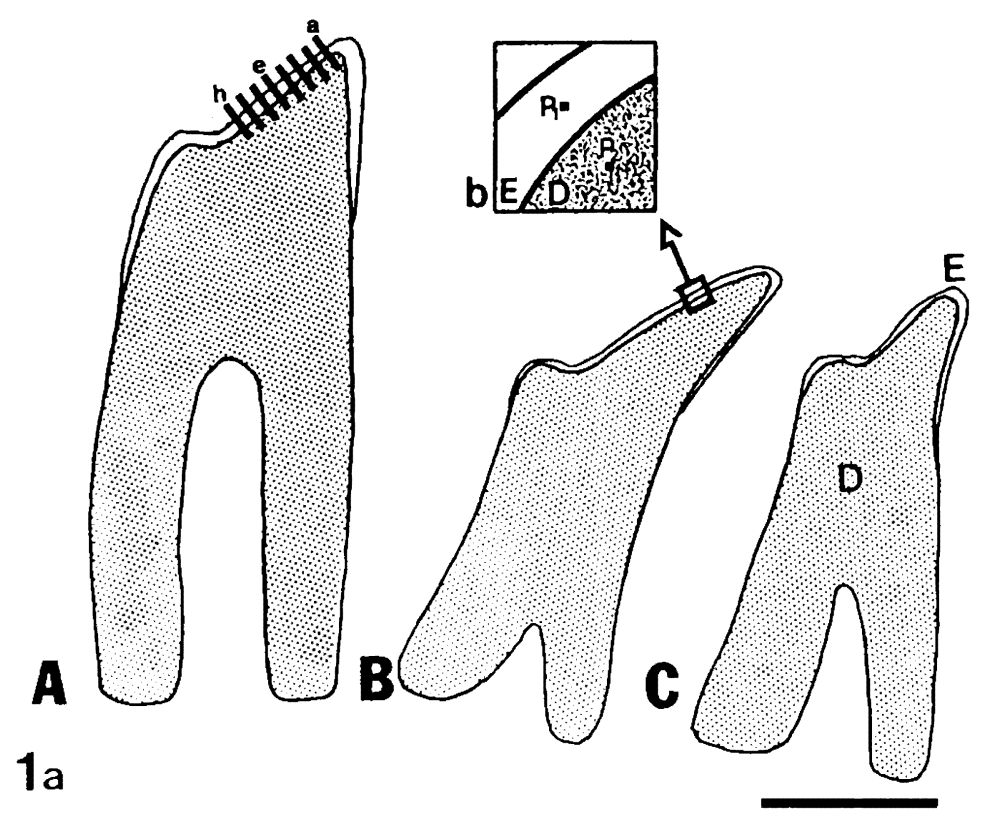

Fig. 1. (a) Diagram of tooth of Caudata. Sites of scan and point analyses by EMPA are indicated by lines a through $h$ for all specimens. (b) Enlarged diagram shows depth of two probes at cach level $(a-h)$ in the enamel and the dentin. Point P1 is at a depth of about $1 \mu \mathrm{m}-20 \mu \mathrm{m}$ from the surface of the tooth in the enamel layer. Point P2 is about $1 \mu \mathrm{m}-5 \mu \mathrm{m}$ into the dentin from the dentino-enamel junction. Abbreviations: E, enamel; D, dentin; Scale bar $=150 \mu \mathrm{m}$. A, Ambystoma maculatum; B, Salamandra salamandra; $\mathrm{C}$; Aneides lugubris 
Table 2. Characteristics of caudata teeth enamel observed by Transmission clectron microscopy (TEM).

\begin{tabular}{lccc}
\hline Species & $\begin{array}{c}\text { Tip of enamel } \\
\text { thickness } \\
(\mu \mathrm{m}) \\
\text { mean }\end{array}$ & $\begin{array}{c}\text { Enamel } \\
\text { crystal } \\
\text { arrangement } \\
\text { type }\end{array}$ & $\begin{array}{c}\text { **DEJ } \\
\text { mineral } \\
\text { density }\end{array}$ \\
\hline $\begin{array}{l}\text { Ambystoma maculatum } \\
\text { Aneides lugubris }\end{array}$ & 28.0 & $\begin{array}{c}\text { mixed } \\
\text { right angle } \\
\text { mixed }\end{array}$ & $\begin{array}{l}\text { high } \\
\text { high } \\
\text { low }\end{array}$ \\
\hline
\end{tabular}

** DEJ, Dentino-enamel junction.

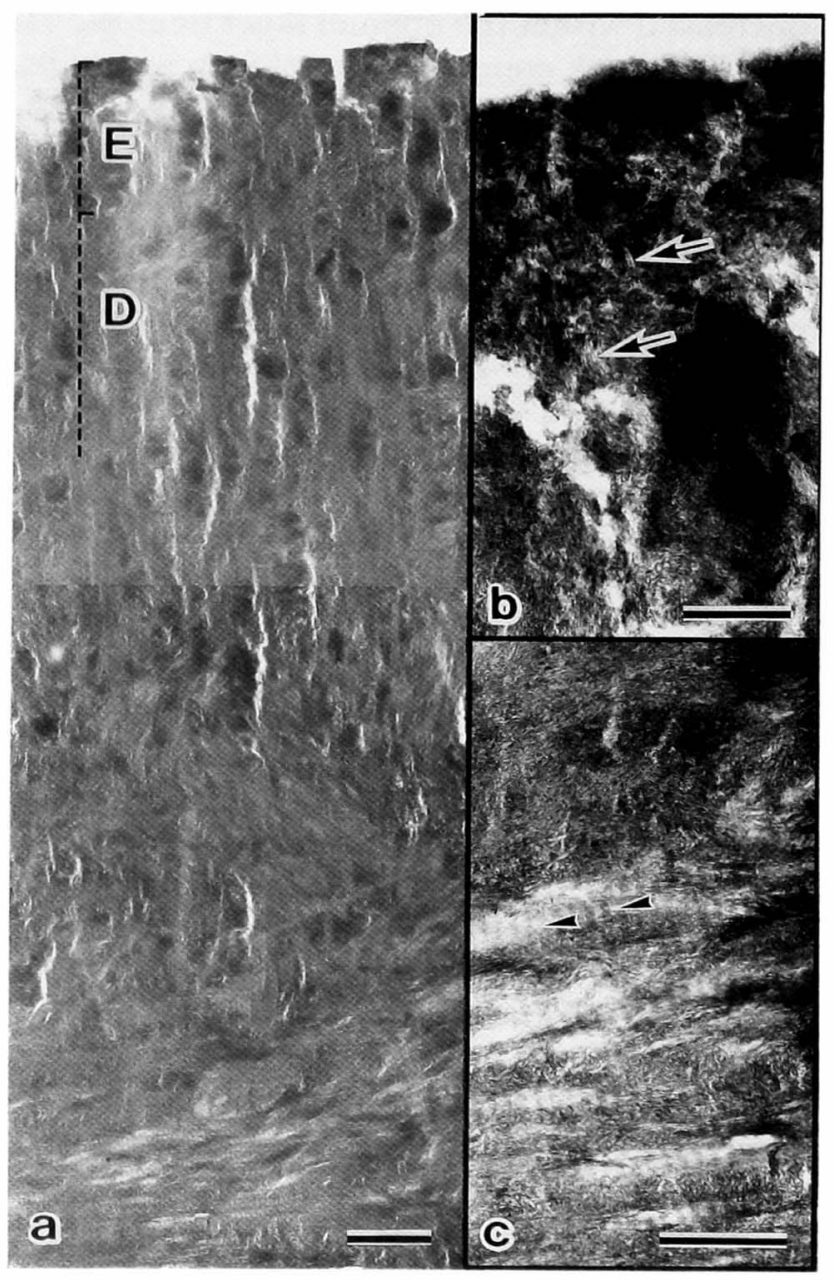

Fig. 2. TEM photographs of bucco-lingual sections of tooth in Ambystoma maculatum. a: Vicw of cnamel (E) and dentin (D) layers $(\mathrm{bar}=1 \mu \mathrm{m}), \mathrm{b}$ : small masses with mineral crystals are found in the inner part of the enamel layer. These electron-dense crystals (arrow) are oriented irregularly but predominantly at right angle to the tooth surface (bar $=250 \mathrm{~nm})$, c: Collagen fibers are found in the inner dentin layer (arrowhead) (bar $=500 \mathrm{~nm})$.

(Figs. 2-4). In Aneides, the arrangement of packed matrices in the high density dentin of the beneath enamel layer was very complex in contrast to other

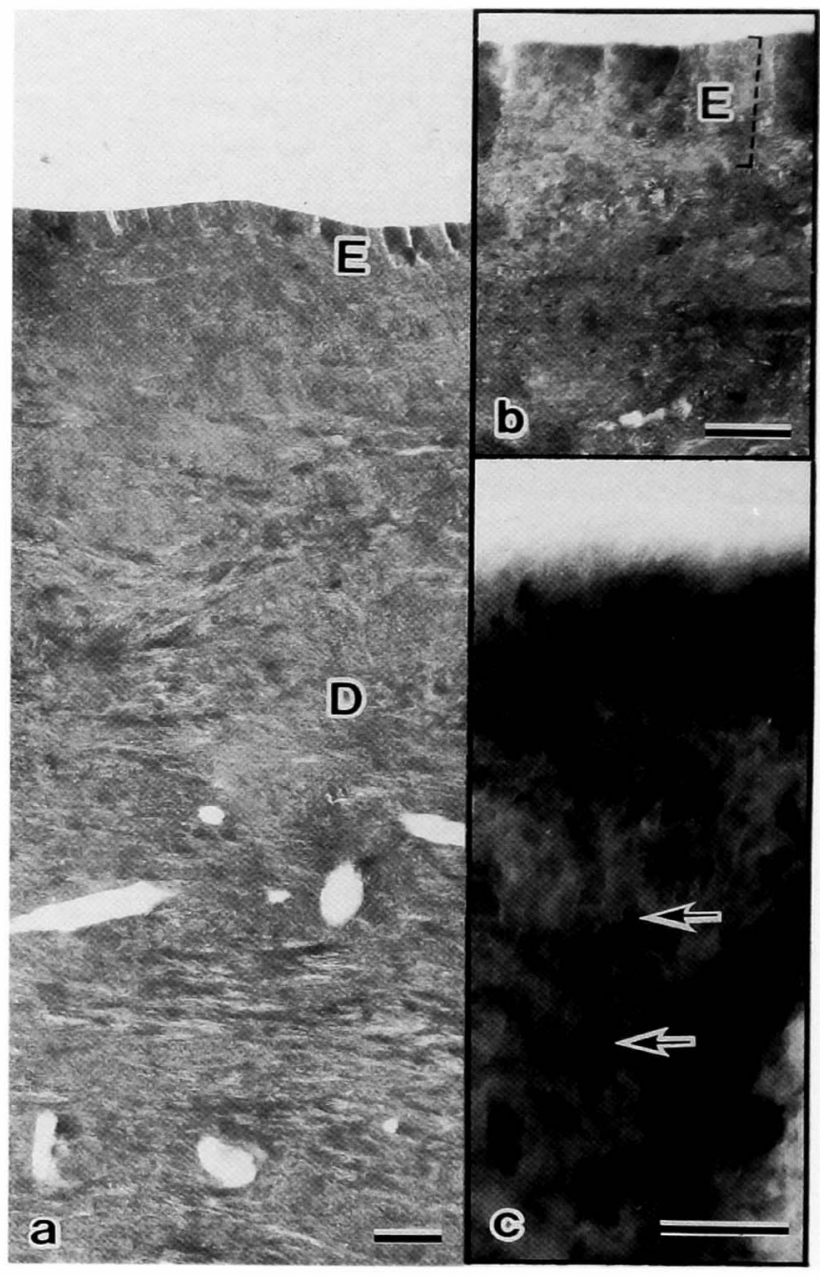

Fig. 3. TEM photographs of bucco-lingual sections of tooth in Salamandras: a: Very thin enamel layer (E) and large part of the tooth dentin layer (D) which composed of irregularly arrangements collagen fibers $(\mathrm{bar}=1 \mu \mathrm{m}), \mathrm{b}$ : Very small mineral crystals in the cnamel layer, showing compacted into dense aggregates with prism-like blocks, are regularly arranged at right angle to the tooth surface (bar $=250 \mathrm{~nm})$, c: Enlargement of region of cnamel laycr, showing high electron-dense crystal (arrow) which regularly arranged to the tooth surface $($ bar $=50 \mathrm{~nm}$ )

dentin layer which many crystals arranged regularly (Fig. 4).

\section{EMPA analysis}

\section{Elements concentration}

Principal concentration in the tooth calcium concentration level in the enamel layer of Ambvstoma and Aneides varied at each level measured, in contrast to that of the dentin layer except for Salamandra (Fig. 5a). The concentration of calcium in the enamel layer was somewhat lower than that of dentin laver (Fig. 5a, b). In Ambvstoma, Salamandra, and Aneides, the peak calcium concentration occurred in the outer part of the enamel laver, gradually to decrease within the enamel to a point near the DEJ. 


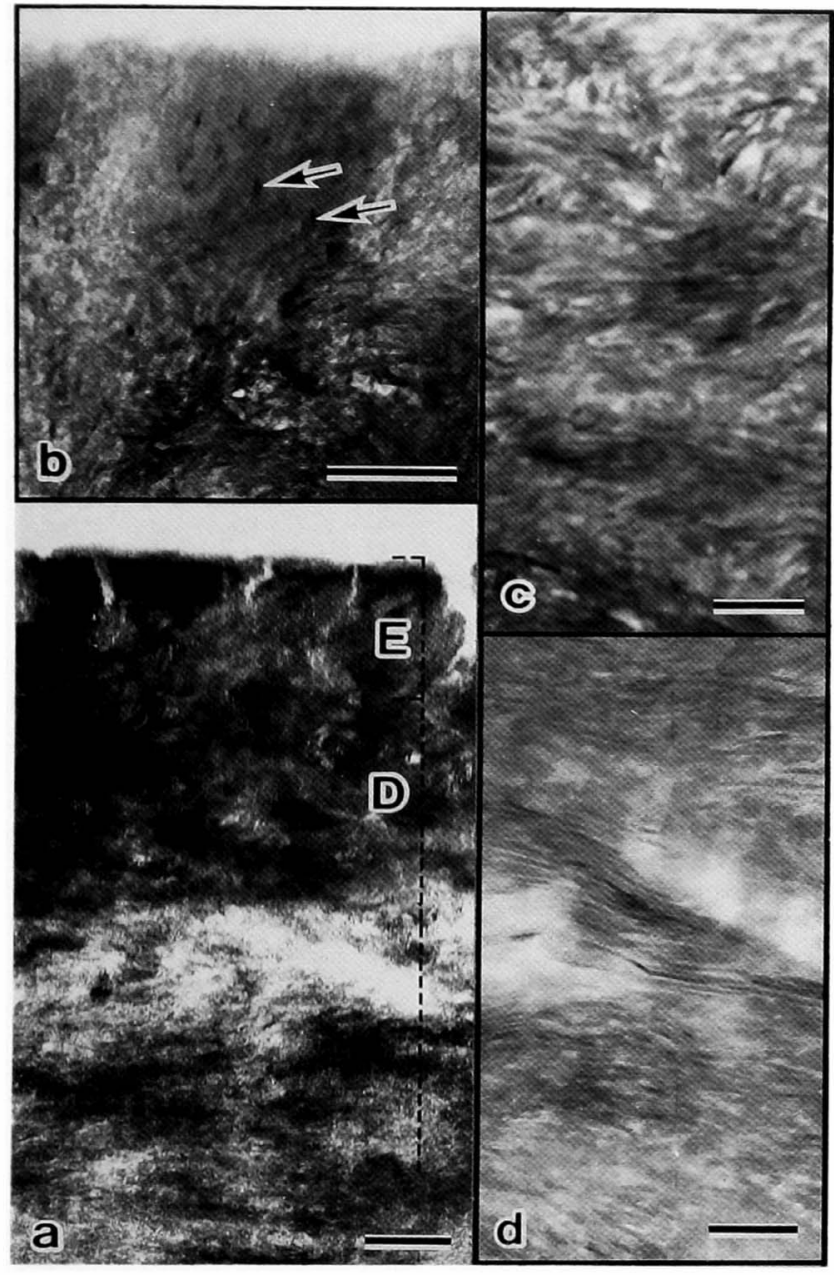

Fig. 4. TEM photographs of bucco-lingual sections of tooth in Aneides lugubris. a: Mineral crystals in the outer part of the enamel layer (E) are compacted into dense aggregates with form prism-like blocks. In the inner part of the dentin layer (D), Electron-dense crystals are oriented irregularly but parallel to the long axis to the tooth (bar $=250 \mathrm{~nm})$. b: Small pin-like crystals (arrow) in the outer part of the enamel layer, showing high density, are oriented at right angle to the tooth surface $(\mathrm{bar}=100 \mathrm{~nm}) ; \mathrm{c}$ : The beneath of the EDJ has pin-like crystals which are irregularly arranged $(\mathrm{bar}=50 \mathrm{~nm})$, d: In the inner dentin layer, thin and pinelike crystals are found near the collagen fibers $(\mathrm{bar}=50 \mathrm{~nm})$.

It then rose precipitously to levels above those for enamel in the dentin (Fig. 6). In the tooth of Aneides, the calcium content increased substantially at level $\mathrm{f}$ and level $\mathrm{g}$ in the basal enamel portion. The calcium content of the enamel layer of Ambystoma was gradually increased from a to g levels (Fig. 5a). The calcium content in the enamel layer of Salamandra was relatively constant at all levels (Fig. 5a). In the dentin layer of their teeth, the calcium concentration was constant at all examined levels (Fig. 5b). The phosphorus content in the enamel and dentin layers remained relatively constant below 20 atoms \% at all level and depth. The phosphorus content level of which in Salamandra was higher than that of others (Fig. 5c, d). Magnesium increased in concentration from the DEJ to the dentin layer, and remained relatively constant at all level in the dentin layer (Fig. 5e, f). The magnesium content in the enamel layer of Ambystoma was the highest of all (Fig. 5e). In Ambystoma and Aneides, the magnesium content of the dentin was higher than that of the content in Salamandra (Fig. 5f).

\section{Trace elements concentration}

There was an increase in the iron concentration from the surface inwards the DEJ increases from the surface towards the inner part of the enamel layer, and decreased within the enamel layer near the DEJ (Fig. 6). The peak concentration of iron was highest at about 6.2 atoms \% (level b), in the inner part of the enamel layer of Aneides, although the content of level decreased from the tip toward the basal portion of the tooth (0.42 atoms \%, level h) (Fig. 6). This tendency was also found in the tooth of Salamandra in contrast to the tooth of Ambystoma (Fig. $5 \mathrm{~g}$ ). The peak concentration of fluorine occurred in the middle enamel layer about $10-20 \mu \mathrm{m}$ (Fig. 7). In Aneides and Salamandra, the fluorine content remained constants at all levels of the enamel layer. In Aneides, the fluorine content in the dentin layer was higher than that of other species (Fig. 5h, i).

\section{Discussion}

There are various crystal arrangements in the enamel layer of the amphibian teeth by TEM observations (Sato et al., 1991; Sato et al., 1992). Two principal pattern of arrangements of crystals of the enamel: parallel (Type 1) and right angles to the long axis of the tooth (type 2), are revealed by TEM and supported by EMPA (Sato et al., 1992). In our study, irregularly arrangement crystals (mixed type) is found in our examined enamel layer of the teeth. Despite of the difficulties separation of the enamel layer as the outer and inner layers by TEM observations, the structure of the inner part of the enamel layer are clearly found in Aneides. These structures and the beneath the DEJ in Aneides resemble to the enamel layer of the adult tooth of Onychodactylus japonicus (Sato et al., 1991) and the enameloid of the teeth in Hynobius nigrescens and Triturus pyrrhogaster (Kawasaki and Fearnhead, 1983). In morphological observations the inner part of the enamel layer in the tooth of Aneides, also resembles to the enameloid in teeth of Ambystoma and Triturus (Meredith Smith and Miles, 1971). Amystoma has two morphological features in developed stages from that same dental lamina as monocuspid (larval) and 

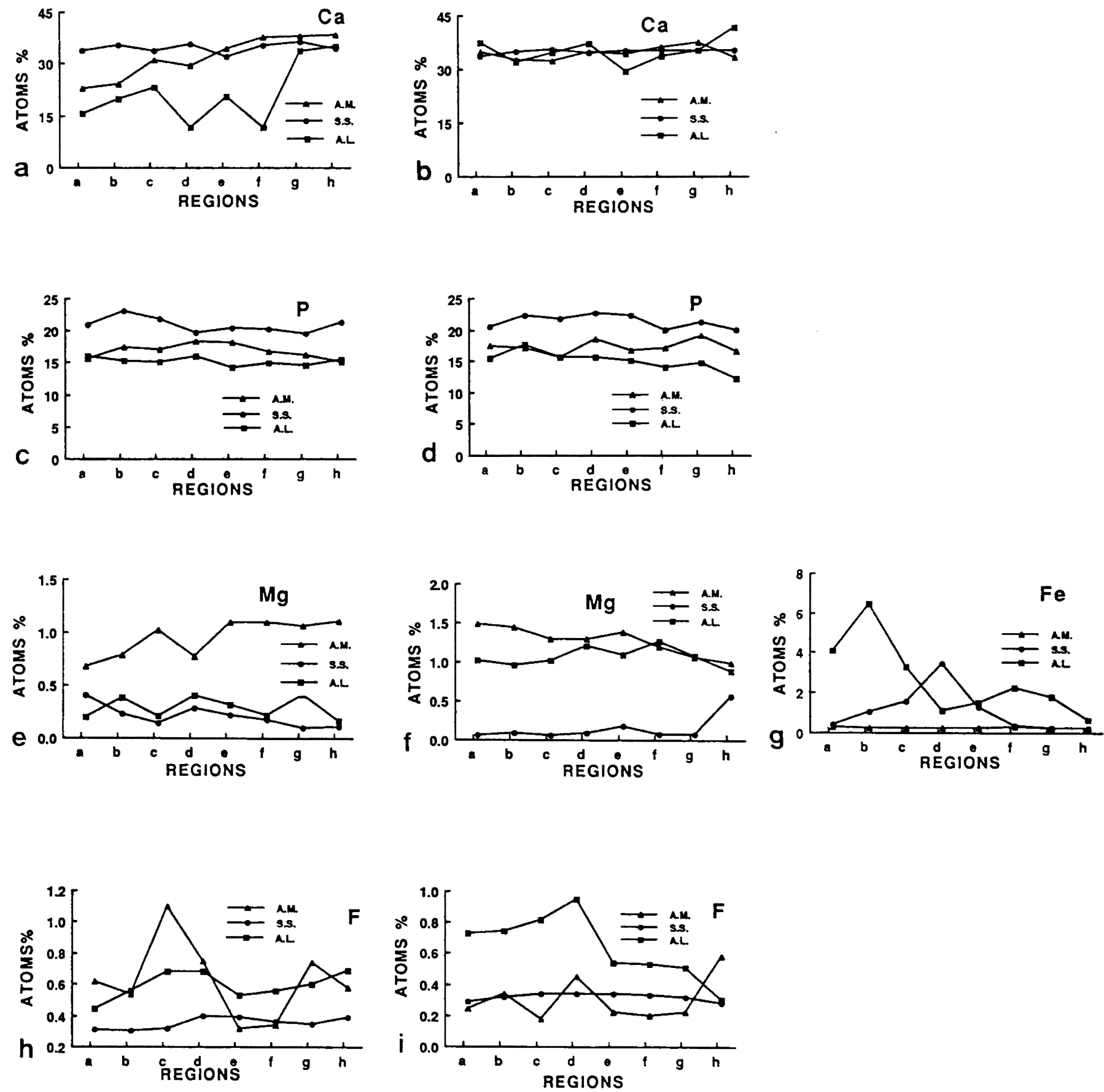

Fig. 5. Graphs showing probe microanalysis of $\mathrm{Ca}, \mathrm{P}, \mathrm{Mg}, \mathrm{Fc}$, and $\mathrm{F}$ distribution in the tooth at apico-basal levels a to $\mathrm{h}$ (see Fig. 1), utilizing longitudinal sections. The values for each group are averages of 3-9 individual analyses. Atoms \% of Ca. $\mathrm{Mg}, \mathrm{Fe}$, and $\mathrm{F}$ are calculated from concentrations in magnesium fluoride. potassium ferrocyanide, and fluorapatite. $\mathrm{a}-\mathrm{b}, \mathrm{Ca}$ : $\mathrm{c}-\mathrm{d}, \mathrm{P} ; \mathrm{e}-\mathrm{f}, \mathrm{Mg} ; \mathrm{g}, \mathrm{Fe} ; \mathrm{h}-\mathrm{i} . \mathrm{F}$ (a) Ca concentrations in the enamel layer increase slightly from tip of the tooth toward the root except for Aneides in which low content at d, c, f points. (b) Ca concentrations in the dentin layer are approximately constant at each point. (c) $P$ concentrations in the cnamel layer are approximately constant at each points. (d) $P$ concentrations in the dentin layer are also approximately constant at each points. (c) $\mathrm{Mg}$ concentrations in the cnamel layer are low content at each points except for Ambystoma in which $\mathrm{Mg}$ content slightly increases from tip of the tooth toward the root. (f) $\mathrm{Mg}$ concentrations in the dentin layer are gradually increase from tip of the tooth toward the root except for Salamandra in which Mg content is very low. (g) Fe concentration in the cnamcl layer of Aneides decreases from tip of the tooth toward the root in contrast to other species. (h) $\mathrm{F}$ of profiles in the enamel layer show approximately various concentration. (i) $\mathrm{F}$ of profiles in the dentin layer also show approximately various concentration. A.M. Ambystoma maculatum; S.S. Salamandra salamandra: A.L., Aneides lugubris.

bicuspid (adult). In the bicuspid tooth of Amystoma, the enameloid is not found and could not be distinguished two layers (enamel and enameloid). The results suggest that the enameloid only exists in a larval tooth of Amystoma. In generally. there are three different feature of enamel. a) the large apatite crystals, b) the lack of collagen fibers, c) presence of minute residues of organic matrix in the subtance of 


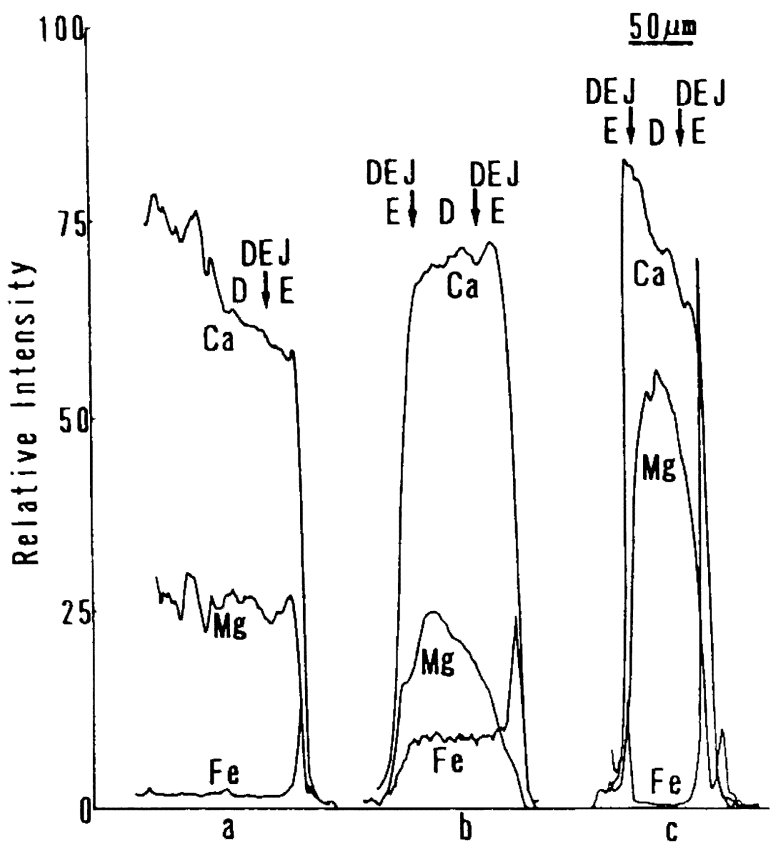

Fig. 6. Profiles obtained by EMPA, utilizing two probes $(b, c)$ along a bucco-lingual line across the tooth from buccal surface of enamel layer to lingual surface of enamel layer at levels near the tip of tooth and one probes (a) along a line scanning from buccal region of the dentin layer to the lingual surface of enamel layer at levels near tip $(a-b$ levels, see Fig. 1a). Ordinate show the relative intensity of the elements. Arrows indicate the opposite DEJ borders of longitudinal section. The sharp rise and fall in intensity for each profiles represents the outer margin of the enamel. (a) $\mathrm{Ca}, \mathrm{Mg}$, and $\mathrm{Fe}$ profiles of; Ambystoma maculatum; Same for (b) Salamandra salamandra, (c) Aneides lugubris.

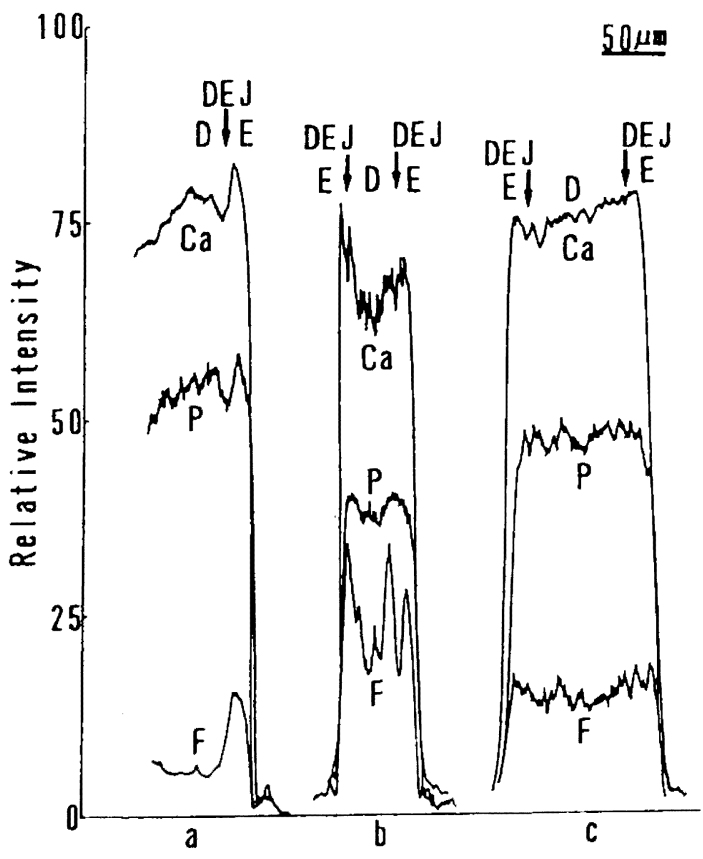

Fig. 7. Profiles obtained by EMPA, same for Fig. 6 (a) $\mathrm{Ca}, \mathrm{P}$ and $\mathrm{F}$ profiles of Ambystoma maculatum same for (b) Salamandra salamandra, (c) Aneides lugubris. tissue (Fearnhead, 1979). In our TEM observations, the lack of collagen fiber found in the enamel layer of teeth in contrast to the enamel layer of the tooth in Cryptobranchus alleghaniensis and Dermohis sp. (Sato et al., 1992).

In Aneides, the enamel layer could not be clearly separated into two parts by EMPA analysis in contrast to the rat incisors (Ishida et al., 1983) in spite of the morphological features as two parts of the enamel layer in Ambystoma and Aneides such as the tooth of American alligator (Sato et al., 1990). However, the apatite crystals of the enamel layer of our examined teeth are small in compared with Mammals' (Rönnholm 1962), they are larger than that in the dentin layer. Therefore, the inner part of the enamel layer is 'true enamel' as Fearnhead hypothesis (1979). The calcium concentration differentiate the enamel layer and dentin layers in the present work. The profiles of calcium levels is higher in the dentin compared of its in the enamel layer. Moreover, the profiles of the magnesium level in the enamel and dentin layers are different in our examined species. The dentin layer toward the dentino-enamel junction of the tooth in Ambystoma and Salamandra are more highly crystallized than that in the enamel layer. Okazaki et al. (1986) reported that the magnesium level was involved in the crystallization of apatite in the tooth. The magnesium content is related to the crystallization of the enamel and dentin layers. Our EMPA analysis as highly magnesium contents of Ambystoma tooth indicate the morphological features as high mineralized crystals.

In tetra-odontiform fishes, iron (up to $0.4 \%$ ) is deposited in the enameloid layer (Suga et al., 1989). In Andrias davidianus and Onychodactylus japonicus, concentration of iron $(12.5 \%)$ is located in the outer part of the enamel layer (Sato et al., 1991). In the American alligator, iron $(3.0 \%)$ is also deposited in the surface of enamel layer (Sato et al., 1990). Suga et al. (1989) believed that the content of trace elements in the teeth of fishes is related to their phylogeny. However, the trace elements deposited in the tooth varies in our examined species. Our results show the concentration of iron to be located in the inner part of the enamel layer up to $6.2 \%$ from the surface of the tooth in Aneides, that is, a low calcium in the outer part of the enamel layer of Aneides together with that iron concentration. The iron distribution in the enamel layer suggest that iron incorporate into apatite crystals in structure of enamel as iron-containing fluoridated hydroxyapatites during teeth development suggested by Randall (1966) reported ferritin in the developing teeth of amphibian (Ambystoma and Triturus). The concentration of fluorine is found in the enamel and 
dentin layers. Nelson et al. (1989) suggested that the ingested fluoride was transported to the mineralization front of the developed tooth and the deposited fluorine was incorporated into apatite crystals in structure of enamel and dentin layers. Brudevold and Söremark (1967) reported that the content of trace elements of the human tooth is related to the environmental water and their feeding habits. These reports suggest that fluorine distribution in amphibian teeth is related to the formation of the tooth and environment resemble to mammals' of the enamel layer (Appelgren et al., 1961; Hammarstöm, 1971), alligator (Sato et al., 1990), amphibians (Sato et al., 1991, 1992) and fishes (Suga et al., 1981; Suga et al., 1983).

We conclude that the morphological feature of the enamel layer in our examined amphibian species is related the distribution and deposited mineralizing elements and trace elements during teeth formation and the differentiates of these levels among our examined species in spite of differences in biosphere compare to other Caudata and Apoda.

\section{Acknowledgments}

We would like to thank Dr. Harold Fox (Department of Biology, University College London, U.K.) and Dr. Ogawa Masaaki (Dental Research Institute, Nippon Dental University, Tokyo, Japan) for their unstinting kindness and help.

\section{References}

1) Appelgren LE, Ericsson $Y$ and Ullberg S. A comparison of the distribution of radioactive fluorine and calcium by use of double isotope autoradiography. Acta Physiol Scand 1961;53:339-347.

2) Brudevold $F$ and Söremark R. Chemistry of the mineral phase of the enamel. In Miles, A. E. (ed), Structure and chemical composition of tecth. Academic Press, New York. 1967;247-277.

3) Fearnhead RW. Matrix-mineral relationships in enamel tissue. J Dent Res 1979;58:909-921.

4) Hammarström L. Distribution in developing rat enamel of simultaneously injected fluoride and calcium. Scand J Dent Res 1971:79:369-376.

5) Halse A. An electron microprobe investigation of the distribution of iron in rat incisor cnamel. Scand J Dent Res 1972;80:26-39

6) Halse A and Selvig KA. Incorporation of iron in rat incisor enamel. Scand J Dent Res 1974:82:47-56.

7) Heap PF, Berkovitz BKB, Gillett MS and Thompson DW. An analytical ultrastructural study of the iron-rich surface layer in rat-incisor enamel. Archs Oral Biol 1983:28:195-200.

8) Ishida $T$, Ogawa $Y$ and Yagi $T$. Effects of fluoride injection on the enamel formation in rats. In Suga $S$. (ed), Mechanism Tooth Enamel Formation, Quintessence, Tokyo. 1983;285-303.

9) Kawasaki K and Fearnhead RW. Comparative histology of tooth enamel and enameloid. In Suga S. (ed), Mechanism Tooth Enamel Formation, Quintessence, Tokyo. 1983;229-238.

10) Meredith Smith $M$ and Miles AEW. The ultrastructure of odontogenesis in larval and adult urodeles; Differentiation of the dental epithelial cells. Z Zellforsch 1971;121:470-498.

11) Nelson DGA, Coote GE, Vickridge IC and Suckling G. Proton microprobe determination of flourine profiles in the enamel and dentine of crupting incisors from sheep given low and high daily doses of fluoride. Archs Oral Biol 1989:34:419-429.

12) Okazaki $\mathbf{M}$, Takahashi $\mathbf{J}$ and Kimura $\mathbf{H}$. Crystallinity and solubility behavior of iron-containing fluoridated hydroxyapatites. J Biomed Mate Res 1986:20:879-886.

13) Randall $M$. Electron microscopical demonstration of ferritin in the dental epithelial cells of urodeles. Nature 1966:210: $1325-1326$.

14) Rönnholm $E$. The amelogensis of human teeth as revealed by electron microscopy. II The development of the enamel crystallites. J Ultrastruc Res 1962:6:249-303.

15) Sato I, Shimada K, Yokoi A, Handal JC, Asuwa N and Ishii T. Morphology of the teeth of the American alligator (American mississippiensis): Fine structure and chemistry of the enamel. J Morphol 1990;205:165-172.

16) Sato I, Shimada K. Sato T and Kitagawa T. Fine structure and elemental analysis of the enamel in Andrias davidianus (Cryptobranchidae) and Onychodactylus japonicus (Hynobiidae). J Herpctol 1991;25:141-146.

17) Sato I, Shimada K and Sato T. Morphology of the teeth of adult Caudata and Apoda: Fine structure and chemistry of enamel. J Morphol 1992:214:1-10.

18) Schmidt WJ. Enamel. In Schmidt WJ and Keil A. (eds), Polarizing Microscopy of Dental Tissues. Pergamon Press, Oxford. 1971:430-459.

19) Suga S, Wada $K$ and Ogawa $M$. Fluorine concentration in teeth of tetra-odoniform fishes and its phylogenetic significance. Jpn J Ichthyol 1981:28:304-312.

20) Suga S, Wada K and Ogawa M. Fluorine concentration in teeth of perciform fishes and its phylogenetic significance. Jpn J Ichthyol 1983:30:81-93.

21) Suga S, Wada K, Taki Y and Ogawa M. Iron concentration in teeth of tetra-odoniform fishes and its phylogenetic signifcance. J Dent Res 1989;68:1115-1123.

22) Weatherell JA, Deutsch D, Robinson C and Hallsworth AS Fluoride concentrations in developing enamel. Nature 1975; 256:230-232.

23) Zaki AE and Weber DF. Microradiography of the mineralization pattern in developing tecth of the frog. Rana pipiens. Archs Oral Biol 1979:24:651-655. 